the haemodynamically normal and malfunctioning valve. Hence heterografts do not appear to act as "foreign material" in the circulation. The results are also consistent with the view that a major cause of the haemolytic disorder after valve replacement by artificial valve prostheses is valvular turbulence with mechanical damage to red cells. In addition it appears that foreign materials other than prosthetic valves, such as pacing catheters or Dacron aortic grafts, may be implicated in mechanical haemolysis of red cells.

This study was supported by the National Health and Medical Research Council of Australia. We thank Dr. H. Smith, of the Department of Pathology, Royal Brisbane Hospital, and Dr. B. J. Stephens, of the Department of Pathology, Chermside Hospital, for their co-operation and help, and Drs. G. H. Neilson and E. G. Galea for allowing us to study patients under their care.
REFERENCES

Bell, R. E., Petuoglu, S., and Fraser, R. S. (1967). Brit. Heart 7., 29, Brodeur, M. T. H., Sutherland, D. W., Koler, R. D., Starr, A., Kimsey, J. A., and Griswold, H. E. (1965). Circulation, 32, 570.
Eyster, E., Mayer, K., and McKenzie, S. (1968). Ann. intern. Med., 68, $\frac{\mathrm{Q}}{\mathrm{C}}$ Marsh, G. W. (1964). Lancet, 2, 986. Nevaril, C. G., Lynch, E. C., Alfrey, C. P., jun., and Hellums, J. D. $\frac{\overrightarrow{\bar{N}}}{\square}$

O'Brien, M. F., and Clarebrough, J. K. (1966). Med. F. Aust., 2, 228.

O'Brien, M. F., and Clarebrough, J. K. (1967). Lancet, 1, 929.

Pirofsky, B., Sutherland, D. W., Starr, A., and Griswold, H. E. (1965). New Engl. ₹. Med., 272, 235 .

Roeser, H. P., Powell, L. W., and O'Brien, M. F. (1968). Unpublished. $\stackrel{\mathbb{D}}{\circ}$ Rubinson, R. M., Morrow, A. G., and Gebel, P. (1966). Amer. Heart 7., 71, 179.

Sayed, H. M., Dacie, J. V., Handley, D. A., Lewis, S. M., and Cleland, W. P. (1961). Thorax, 16, 356 .

Stevenson, T. D.; and Baker, H. J. (1964). Lancet, 2, 982.

Trinder, P. (1956). 7. clin. Path., 9, 170.

Veall, N., and Vetter, H. (1958). Radioisotope Techniques in Clinical $\mathscr{O}^{\omega}$ Research and Diagnosis. London.

\title{
The Drunk in Court : Survey of Drunkenness Offenders from Two London Courts
}

\author{
DENIS GATH, $* \|$ B.M., M.R.C.P., D.P.M. ; CELIA HENSMAN, $\dagger$ M.A. ; ANN HAWKER $\dagger$ \\ MICHAEL KELLY, $\ddagger$ M.D., D.P.M. ; GRIFFITH EDWARDS,§ D.M., D.P.M.
}

\begin{abstract}
Cummary : A total of 151 men charged with drunken$\checkmark$ ness with or without aggravations were interviewed immediately after their appearance before the magistrates. The survey was conducted in two Metropolitan courts; one in an area frequented by vagrants, and the other in a mixed middle-class and working-class area.

Few of the offenders were casual roisterers and the majority had a serious drinking problem. Half the offenders showed evidence of chemical dependence on alcohol as determined by morning shakes, morning relief drinking, amnesias, inability to stop drinking, and hallucinatory experiences.

The majority of the offenders were suffering from gross social isolation.

Existing ways of dealing with such men seem inadequate. A rehabilitation service is needed, with hostel accommodation, and particular attention should be paid to first offenders.
\end{abstract}

\section{Introduction}

The problem of society's response to the drunkenness offender is at present much under discussion. A Home Office working party is currently reviewing the question of "the treatment, within the penal system, of persons who habitually commit offences involving drunkenness." Its deliberations have been given urgency by Section 91 of the Criminal Justice Act, 1967 (H.M.S.O., 1967), which proposes that imprisonment for a "drunk and disorderly" offence be abolished as soon as alterna-

* Senior Registrar.

Tenior Lecturer, Karolinska Institute, Stockholm.

₹ Senior Lecturer,

Institute of Psychiatry, Maudsley Hospital, London S.E.5.

I| Present address: Department of Psychiatry, Queen Elizabeth Hospital, Birmingham 15

From the Alcohol Impact Project, Addiction Research Unit, Institute of Psychiatry, De Crespigny Park, London S.E.5. tive accommodation is available for the care and treatment of offenders. The first International Congress on the Drunkenness

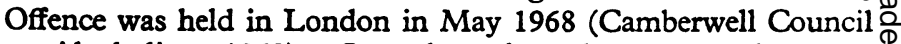
on Alcoholism, 1968). Several speakers there reported a move $\varrho$ in other European countries and the U.S.A. to treat the public $\overrightarrow{\overrightarrow{0}}$ inebriate as a sick person and to exclude him entirely from the $\exists$ courts and from the criminal process.

Every year in England and Wales there are approximately 75,000 convictions for drunkenness with or without "aggravations," a number which makes heavy demands on the resources of the police and courts. Yet little is known about the kind of 0 person the drunkenness offender is, and the impact on him of 3 . arrest and conviction is little understood. The official statistics $\delta$ are limited to an analysis of drunkenness offences by geo- $\overline{3}$ graphical regions, and by sex and age of offenders (H.M.S.O., 0 1968). Offences of this kind are not recorded centrally, and there is no indication of what proportion of them are caused by $\sigma$ habitual offenders and what proportion by "once only" $\frac{D}{O}$ offenders. Prison records are not helpful here, there being no reason to suppose that inebriates in prison are representative of $N$ drunkenness offenders as a whole. Previous surveys in the court N్ setting have been carried out in London (Parr, 1962), Rochester, 0 U.S.A. (Zax et al., 1964), and Toronto (Giffen, 1966-8); these studies were of limited scope, as they did not include interviews $\frac{\widetilde{\Phi}}{\mathbb{D}}$

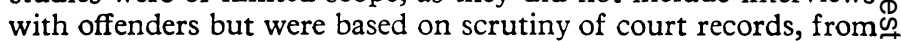
which only simple demographic data can be drawn.

Recently the British Medical fournal (1968) drew attention to the dearth of research information concerning the kinds of people who are arrested for drunkenness, and emphasized that $\stackrel{\mathbb{Q}}{\Omega}$ "the proportion of drunkenness offenders who are casualo roisterers as opposed to people with serious drinking problems or sufferers from alcohol dependence remains obscure." TheO answer to this question is relevant to any discussion regarding reform of the law and the design of therapeutic alternatives to fine or imprisonment: the aim of the present investigation was to obtain information bearing directly on this question. More specifically, the aim was to interview a sample of men appearing 
in London courts on drunkenness charges, in order to study their social and psychological characteristics and to determine (1) what proportion showed evidence of chemical dependence on alcohol, and (2) what proportion were suffering from social breakdown and isolation.

\section{Method}

Ideally, sampling would have been carried out at all the 16 Metropolitan magistrates' courts, but in the course of extensive inquiries at these courts it became clear that this was impracticable for several reasons, such as lack of interviewing space. Two courts were therefore selected as being representative of contrasting types of area, the one (court A) in a poor and rundown quarter where vagrants tend to congregate, the other (court B) in a mixed working-class and middle-class residential area. Drunkenness offenders were interviewed by a psychiatrist (D. G., G. E., M. K.) or by a research assistant (C. H., A. H.) who had previous experience in alcoholism studies. A semistructured interviewing schedule was used which consisted of 80 questions and took 20 to 30 minutes to complete. In prepilot work, interviews were tape-recorded and subsequently discussed by the investigators in a group, so that uniformity of interviewing techniques and precise agreement on criteria were achieved. A six-week pilot study consisting of 47 interviews was then carried out in the two courts and the schedule revised.

The definitive study ran from 1 September 1967 to 16 January, 1968, and consisted of 151 interviews, of which 84 were at court $A$ and 67 at court $B$. Interviewing was carried out every Monday, Wednesday, Friday, and Saturday, using a simple fortnightly rota so that visits to the two courts were evenly distributed over the days of the week. Offenders were seen immediately after appearing before the magistrates, and participation was voluntary. Only male subjects charged with a drunkenness offence were included in the survey ; motoring and other drinkassociated offences were excluded.

The sampling procedure was to interview the first two offenders passing through the court each day, and as many of the rest as time permitted. No bias was introduced by this procedure, because the order of appearance in court is determined fortuitously by the varying order in which offenders arrive from various police stations. Supporting evidence that the sample was not biased was afforded by basic data which were collected on the total population of male drunkenness offenders, both interviewed and not-interviewed, passing through the two courts during the survey period.

Information obtained at interview was coded and then analysed by computer. All data were processed for the total sample and for the two courts separately.

Co-operation of Interviewees.-Less than $5 \%$ of men refused to participate in this survey, and $90 \%$ of those who complied were rated as "fully co-operative."

\section{Results}

Of the 151 men in the total sample, $70 \%$ had been charged with being drunk, $22 \%$ with being drunk and disorderly, and the remaining $8 \%$ with miscellaneous charges such as drunk and indecent, etc. Two-thirds of the total sample had been remanded in custody, while one-third had been allowed bail.

The between-court analyses showed that the great majority of results were similar at the two courts ; findings will not therefore be routinely presented for the courts separately, the results being similar unless otherwise stated.

\section{Demographic Data}

The age range of the total sample $(n=151)$ was $18-79$, the mean age at court $B, 39.4$ years, being significantly lower than that at court $A, 44.0$ years $(P<0.05)$. There was a preponderance of men from the lower social classes relative to the country as a whole, as determined by the Registrar General's Classification of occupational status: classes I and II $2 \%$, class III $27 \%$, class IV $18 \%$, class V $48 \%$, not classifiable $5 \%$. The offenders' country of birth was given as England $36 \%$, Southern Ireland $34 \%$, Scotland $13 \%$, Northern Ireland $4 \%$, Wales $3 \%$, coloured $2 \%$, other $8 \%$. There was an excess of those reared in the Catholic faith-R.C. 58\%, Established Church 33\%, Nonconformist $4 \%$, Jewish nil, other $5 \%$. Of the total sample $56 \%$ had never married; only $17 \%$ were living with their wives; $11 \%$ were divorced or legally separated, while $11 \%$ had a non-legal separation; $3 \%$ were widowed; $2 \%$ admitted cohabiting.

\section{Circumstances of Arrest}

In response to inquiry about the circumstances of the drinking that led to arrest, $9 \%$ of the total sample named a celebration or special social event such as an anniversary, party, or club meeting; $2 \%$ stated that they were seeking consolation after a traumatic event such as a bereavement or loss of job; while $17 \%$ said they were drinking because it was pay-day. The great majority ( $70 \%$ ) could give no special reason for drinking, or reported simply that they were bored or lonely. Of the offenders $37 \%$ had been entirely alone while drinking; $30 \%$ had consumed no food during the 24 hours before arrest; and $6 \%$ admitted drinking methylated spirits immediately before arrest.

\section{Previous Drunkenness and Criminal Involvement}

In the 12 months preceding this arrest $21 \%$ of the sample had been arrested for drunkenness once or twice, $10 \%$ from three to five times, $10 \%$ from 6 to 10 times; $6 \%$ from 11 to 25 times, and $4 \%$ over 25 times-that is to say, $51 \%$ had been arrested on at least one previous occasion during the past 12 months; and $24 \%$ admitted to one or more arrests during the four preceding weeks. At some time $26 \%$ had been charged with "property offences," $20 \%$ with other petty offences, and $9 \%$ with offences of violence. Most of these charges appeared to be drink-related. Forty-five per cent. had been in prison at least once, and $24 \%$ had been on probation at some time.

\section{Beverage Choice}

The majority of this sample were habitual beer drinkers, but $18 \%$ admitted that rough cider or cheap wine was their customary drink.

\section{Symptomatology of Chemical Dependence}

Inquiry was made about the subject's experience of alcoholic amnesias and of symptoms usually taken as indicative of chemical dependence, such as morning shakes, morning relief drinking, "loss of control," and hallucinatory experiences.

Amnesias for the night before had been experienced at some time by $79 \%$ of subjects, day-time amnesias by $27 \%$, and amnesias lasting at least 24 hours by $13 \%$. Forty-six per cent. reported having had an alcoholic fugue from which they had "woken up" in a strange part of the town or a distant city with no recollection of how they had journeyed there-an occurrence which we have termed the "journey syndrome."

Morning shakes had been experienced by $62 \%$ of the total sample; $50 \%$ reported morning relief drinking, and half of these ( $25 \%$ of the total) admitted this was habitual. On detailed questioning $49 \%$ of subjects had clearly experienced "loss of control" over their drinking-5\% within the last year only. $24 \%$ for one to five years, and $20 \%$ for a period over five: years.

Seventeen per cent. of subjects were found to have suffercs: from delirium tremens at one time or another, as determinedi strictly by the criteria outlined by Victor and Adams (1953). The syndrome of alcoholic hallucinosis, defined equally rigor- 
ously, was identified in $7 \%$ of the sample, while a further $23 \%$ reported having experienced transient visual or auditory hallucinations.

In every case an attempt was made to assess the severity of the subject's drinking problem by detailed questioning about the pattern of his drinking habits, including his drinking milieu, beverage choice, amount consumed, and frequency and times of day of drinking. Information was also sought concerning social and medical damage resulting from drinking. Thirty-two per cent. had pawned and $24 \%$ admitted begging or stealing to raise money for drinking. Twenty-two per cent. had been barred from hostels, $32 \%$ had had a serious accident and $26 \%$ a head injury resulting in unconsciousness, $16 \%$ had suffered from peptic ulceration, and $8 \%$ indicated that they had attempted suicide at some time.

On the basis of all the above information, at the completion of each interview the investigators attempted to allocate the subject to one of the five categories of alcoholism defined by Jellinek (1961). Table I shows that $24 \%$ of the total sample were not considered to have a serious drinking problem; $26 \%$ were judged to have a serious problem without being chemically dependent on alcohol (alpha alcoholism); while $50 \%$ were showing clear-cut evidence of chemical dependence (gamma, delta, or epsilon), and could therefore be designated "alcoholics" or " alcohol addicts," however broadly or narrowly these terms might be defined.

TABLB I.-Classification of Offenders by fellinek Typology

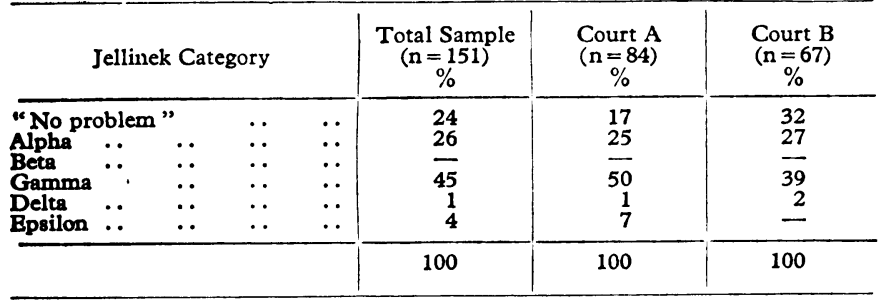

Table II shows the relation between certain factors and classification in the gamma-delta-epsilon as opposed to the alpha or no problem categories. A $\chi^{2}$ test on the distribution of each of the items shows significant differences at the levels indicated.

TABLE II.-Relation of Certain Social Factors to Classification of Offenders by fellinek Typology

\begin{tabular}{|c|c|c|c|c|c|}
\hline & $\begin{array}{c}\text { No } \\
\text { Problem } \\
(\mathrm{n}=34) \\
\% \\
\end{array}$ & $\begin{array}{c}\text { Alpha } \\
(\mathrm{n}=39) \\
\%\end{array}$ & $\begin{array}{c}\text { Gamma, } \\
\text { Delta, } \\
\text { Epsilon } \\
(\mathbf{n = 7 6 )} \\
\%\end{array}$ & $\chi^{2}$ & $\begin{array}{l}\text { Prob- } \\
\text { ability } \\
\text { Level }\end{array}$ \\
\hline $\begin{array}{ll}\text { 1. No fixed abode } & \ldots\end{array}$ & $\begin{array}{r}9 \\
3 \\
24\end{array}$ & $\begin{array}{l}10 \\
26 \\
33\end{array}$ & $\begin{array}{l}33 \\
31 \\
48\end{array}$ & $\begin{array}{r}12 \cdot 0 \\
10 \cdot 2 \\
6 \cdot 2\end{array}$ & $\begin{array}{l}<0.005 \\
<0.01 \\
<0.05\end{array}$ \\
\hline $\begin{array}{l}\text { 4. Usual drink: rough cider/cheap } \\
\text { wine }\end{array}$ & 6 & 8 & 30 & $12 \cdot 3$ & $<0.005$ \\
\hline $\begin{array}{l}\text { 5. More than } 10 \text { arrests for drun- } \\
\text { kenness in past } 12 \text { months .. }\end{array}$ & 0 & 0 & 15 & $11 \cdot 4$ & $<0.005$ \\
\hline $\begin{array}{l}\text { 6. Drugs used regularly at some } \\
\text { time } \ldots \\
. .\end{array}$ & 6 & 3 & 19 & $7 \cdot 7$ & $<0.025$ \\
\hline
\end{tabular}

The contributions of the individual cells to the overall $\chi^{2}$ value indicate that in respect of factors $1,4,5$, and 6 (no fixed abode, usually drinking rough cider or cheap wine, more than 10 arrests for drunkenness in the past 12 months, and regular use of drugs) the alpha and no problem groups resemble one another fairly closely. However, in factor 2 (divorced or separated) the alpha resembles more closely the gamma-deltacpsilon category, and in factor 3 (Irish origin) the three groups are all dissimilar.

\section{Social Isolation}

The majority of offenders were found to be grossly lacking in social support. An indication of this was given by their accommodation at the time of arrest-as shown in Table III, only $42 \%$ had accommodation of their own, in the sense of a house, flat, or furnished room. As mentioned above, only $17 \%$ of the total were married and living with their spouse. Of those who had previously been married $(27 \%)$, very few $(15 \%$ of the subgroup) had any contact with their children or former wife 3 during the preceding 12 months, while $55 \%$ of the total sample $\mathbb{Q}$ had no contact with their parents or siblings in that period.C. Forty per cent. of the offenders had not attended a cinema, $\vec{F}$ dance, church, or other social function in the preceding five years. Less than $10 \%$ belonged to a club, union, or similar organization. Forty-two per cent. had slept in a reception centre and $51 \%$ had slept rough at times. The occupational history of these offenders showed marked instability: at theo time of arrest $40 \%$ were unemployed, while of the employed\% half had been in their current job for under three months and $\overrightarrow{ }$ only a quarter for more than a year. Fifty per cent. had held. more than five jobs in five years. There was a significantly $\vec{\omega}$ higher $(\mathrm{P}<0.01)$ proportion of offenders in social class $V \stackrel{\mathrm{S}}{\mathrm{N}}$ when classified according to their present or most recent job $\frac{0}{3}$ status as against their "best job ever."

TABLE III.-Offenders' Accommodation at Time of Arrest

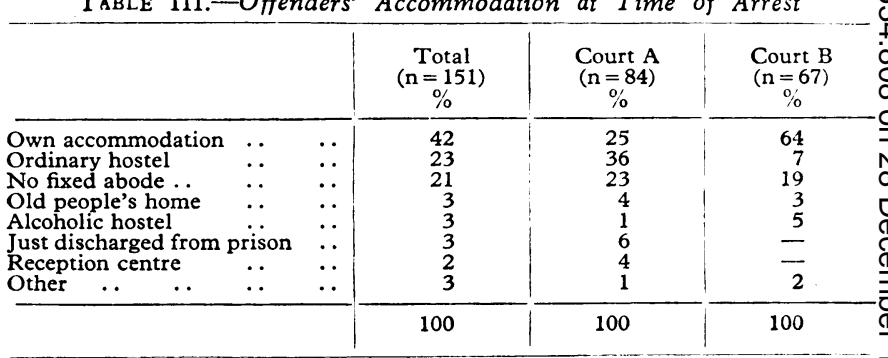

\section{Court Disposal for Current Offences}

This is shown in Table IV. The distribution of disposalss does not differ significantly from that of the total population of $\frac{\supset}{\bar{a}}$ both courts during the study period.

TABLE IV.-Court Disposal for Offences

\begin{tabular}{|c|c|c|c|c|}
\hline Discharge-absolute or $\mathrm{c}$ & ditional & o & ․ & . \\
\hline "10s. or one day" & . & .. & . & .. \\
\hline Fine paid & .. & .. & . & . \\
\hline Fine with time to pay* & . & . & .. & . \\
\hline Prison or remand & - & .. & .. & . \\
\hline
\end{tabular}
* Some of these men were later sent to prison because of failure to pay their fines
within the stated time.

\section{Previous Treatment for Alcoholism}

Past treatments which the offenders reported having received were: psychiatric treatment for alcoholism, $19 \%$; admission to an alcoholics' hostel, $12 \%$; regular attendance at Alcoholics Anonymous meetings, $8 \%$.

\section{Professed Willingness to Accept Help}

The subjects' willingness to accept future help was brieflyb assessed, but with no effort at persuasion or detailed explanation Table $\mathrm{V}$ shows the proportions in the Jellinek alpha-no-problem category as against the gamma-data-epsilon category whe said they would definitely be willing to accept medical or sociato help. A $\chi^{2}$ test showed that the differences were significan at the $0.1 \%$ level.

TABLE V.-Subjects' Attitude to Medical or Social Help by fellinek Classification

\begin{tabular}{|c|c|c|c|c|c|}
\hline & & $\begin{array}{c}\text { No } \\
\text { Problem, } \\
\text { Alpha } \\
(\mathrm{n}=73) \\
\% \\
\end{array}$ & $\begin{array}{c}\text { Gamma, } \\
\text { Delta, } \\
\text { Epsilon } \\
(\mathrm{n}=76) \\
\% \\
\end{array}$ & $\begin{array}{c}\chi^{2} \\
\text { (with } \\
\text { Yates's } \\
\text { Correction) }\end{array}$ & Prubability \\
\hline $\begin{array}{l}\text { Medical help } \\
\text { Social help }\end{array}$ & $\therefore$ & $\begin{array}{l}5 \\
1\end{array}$ & $\begin{array}{l}38 \\
26\end{array}$ & $\begin{array}{l}21 \cdot 2 \\
17 \cdot 1\end{array}$ & $\begin{array}{l}<0.001 \\
<0.001\end{array}$ \\
\hline
\end{tabular}




\section{Discussion}

In discussing the implications of this survey it is necessary to consider how far the populations of these two courts are representative of the country in general. This cannot be determined without further studies in other localities, but two factors suggest that the results may be widely applicable. Firstly, the drunkenness offence is largely a big-city problem, and to this extent it is reasonable to suppose that the results provide a typical picture of the national situation. Secondly, the two courts were selected as being representative of areas with different socio-economic characteristics in the expectation that the results would disclose the main differences between the kinds of drunkenness offender in a run-down city area and those in a stable residential area. To some extent such differences were found, as, for example, in the degrees of " rootlessness" of the two offender populations (Table III). In most respects, however, it is the similarity of the findings at the two courts which calls for comment. It was found, for example, that there were certain between-court differences in types of drinking problem (Table I), and yet the proportions of men showing evidence of chemical dependence were of similar magnitude at the two courts.

There was no check on the reliability of data collected in the survey, and generalizations based on the responses of drunkenness offenders should be made with caution. However, there are several reasons for supposing that the subjects were not motivated to be other than truthful. Interviews were conducted after the court hearing had taken place, and the interviewers emphasized that they were engaged on medical research rather than an "official" inquiry. The internal consistency of the results also suggests their accuracy. In a previous inquiry (Edwards et al., 1966b) responses given by Skid Row alcoholics were found to tally closely with official criminal and hospital records. Furthermore, studies in Toronto (Giffen, 1966-8) have suggested that in surveys of this kind any distortion tends towards an underestimate rather than an overestimate of the extent and severity of pathological drinking and social disruption.

The picture which emerges from this survey is therefore at least an approximate answer to the question posed by the British Medical fournal (1968), cited above. "Casual roisterers" formed a small proportion-slightly less than a quarter-of the sample of drunkenness offenders; men with a serious drinking problem which had not advanced to addiction formed a quarter, while as many as one-half showed evidence of chemical dependence on alcohol. In this survey the diagnosis of chemical dependence was established by strict operational criteria, such as withdrawal symptoms-for example, morning shakes-and the relief of these symptoms by a morning drink. The terms "alcoholism" and "alcohol addiction" are used in many different ways, but in this strict pharmacological sense $50 \%$ of the offenders were suffering from the disease of alcohol addiction. The results further showed that a large proportion of the men were labouring under a gross degree of social breakdown and isolation.

What light does the survey throw on existing methods of treating the public drunk ? In many cases the treatment accorded in the past had been inappropriate or ineffectual$30 \%$ stated that they had been arrested three or more times in the preceding 12 months, while only $19 \%$ reported having had psychiatric treatment for alcoholism, and a mere $12 \%$ had found their way into an alcoholism rehabilitation centre. If the results given in Section 3 with regard to the subject's own reported arrests for drunkenness during the preceding year are taken as applicable to the country as a whole, then it can be estimated that approximately 14,000 males are likely to have been involved in the just over 71,000 male drunkenness offences recorded in England and Wales for the year 1967 (H.M.S.O., 1968); and, further, that of this total of 14,000 males about 7,000 are likely to have been arrested only once during that year; nearly 3,000 two or three times; and just over 4,000 four times or more-perhaps about 500 of these being very frequent recidivists indeed (over 25 arrests each).

In most cases, therefore, the courts are being asked to deal with problems for which judicial processes are inappropriate. If the inference is made that some other method of treatment is called for, and that such men should be cast in the sick role rather than the criminal role, it does not follow that conventional hospital treatment will meet their needs. This is because, after a period of hospital treatment, these men must return to a world in which demonstrably they lack the social skills to survive, having lost or never having possessed such skills.

If present methods of treatment are unsuitable or inadequate, what are the implications of the survey for planning future measures? The guide is probably given by the gross social isolation found in the bulk of the offenders. Their needs are most likely to be met by treating this social isolation in providing a supportive environment (Myerson, 1953) or a therapeutic community which can teach them new skills (Edwards et al., 1966a). At present special hostels for chronic alcoholics are being tried out in London (Cook et al., 1968), and these would seem to be the most promising way of providing the "suitable accommodation" envisaged by the Criminal Justice Act (H.M.S.O., 1967). Such hostels might form part of an integrated rehabilitation service which could include a "shop front" counselling centre and a short-term detoxication centre (Pittman, 1968).

Such a programme inevitably raises the question of the subject's motivation. That $22 \%$ of offenders stated they would accept immediate medical or social treatment suggests a sizable service need. As for the remainder, it would be unjustifiable to dismiss them as "unmotivated" in the absence of services designed to meet their special needs. It has been shown that such men can be responsive to special methods of hostel treatment if these methods are implemented with patience and skill (Cook et al., 1968). The challenge should be accepted of designing services accurately to meet these special needs, following which unmotivated men may well become motivated towards further treatment.

There are grounds, too, for proposing that other measures are required for the casual roisterer. In the popular stereotype the roisterer is usually taken as a figure of fun, but he may well be the alcohol addict of the future. A first incident of public drunkenness may presage serious trouble ahead. Every chronic drunk was once a first offender, and when a man comes up for the first time before the magistrates this may indeed be the live opportunity for early detection of a problem and for an early offer of help.

This research was supported by a grant from the Nuffield Foundation, for which we are most grateful. Thanks are expressed to the magistrates, clerks of court, and gaolers, and to all those men who so kindly agreed to be interviewed. Warm thanks are extended to Miss Jane Chandler for her statistical assistance.

Reprint requests to Celia Hensman at the Institute of Psychiatry.

Brit. med. 7., 1968, 2, 505

\section{REFERENCES}

Camberwell Council on Aicoholism (1968). New Soc., No. 295, p. 756 Cook, T., Morgan, H. G., and Pollak, B. (1968). Brit. med. F., 1, 240. Edwards, G., Hawker, A., and Hensman, C. (1966a). Lancet, 2, 1407. Edwards, G., Hawker, A., Williamson, V., and Hensman, C. (1966b)

Giffen, P. J. (1966-8). Personal communications from Alcoholism and Drug Addiction Research Foundation of Ontario, Canada

Her Majesty's Stationery Office (1967). Criminal Fustice Act. London. Her Majesty's Stationery Office (1968). Offences of Drunkenness, 1967, Cmnd. No. 3663. London.

Jellinek, E. M. (1960). The Disease Concept of Alcoholism. New Haven, Connecticut.

Myerson, D. J. (1953). New Engl. F. Med., 249, 646.

Parr, D. (1962). Brit. F. Crim., 2, 272.

Pittman, D. J. (1968). Existing and Proposed Treatment Facilities in the U.S.A. Paper presented at International Symposium on "The Drunkenness Offence." Institute of Psychiatry, London.

Victor, M., and Adams, R. D. (1953). Ass. Res. nerv. Dis. Proc., 32, 526 Zax, M., Gardner, E. A., and Hart, W. T. (1964). Quart. F. Stud. Alcohol, 25, 669. 